A is for Apple, B is for Bulletproof:

The racialized fortification of schools

Sarah L. Woulfin

University of Connecticut

249 Glenbrook Dr., Storrs, CT 06269

$\underline{\text { sarah.woulfin@uconn.edu }}$

\&

James Sadler

University of North Carolina, Chapel Hill 


\begin{abstract}
From Colorado and Connecticut to Florida, school shootings have struck the U.S. education system, accelerating and deepening the fortification of schools. Fortification entails prioritizing and instituting multiple types of infrastructure, technology, and routines that militarize schools while defining 'safety' as a function of the building and framing educators as responders to gun violence. The school security industry is now a $\$ 2.7$ billion market, so it is vital to comprehend the structures, policies, conceptualizations, resources, and activities linked with school safety. We apply structure-agency theory to advance arguments on the fortification of schools. In particular, we explain the interrelation between racialized school safety policies and practices. Thus, we highlight educators' discretion in enacting safety policy in varied contexts. Our discussion of fortification sheds light on the nexus of guns and schools, operationalizes facets of structure-agency theory, and provides recommendations for research and practice.
\end{abstract}

Keywords: school safety policy, structure-agency theory, policy implementation, school shootings, educational leadership, critical organizational theory 


\section{A is for Apple, $B$ is for Bulletproof: The racialized fortification of schools}

With educational administrators purchasing bulletproof doors and windows for school buildings and families purchasing bulletproof backpacks for children, the school security industry is now a $\$ 2.7$ billion market in the United States (U.S.) (Cox \& Rich, 2018). Aiming to reduce harm from gun violence, numerous school safety policies and practices have become taken for granted and legitimized. For instance, two-thirds of high schoolers in the U.S. attend a school that employs a police officer (Lindsay, Lee, \& Lloyd, 2018), and nearly a third of states have adopted laws that encourage or require active shooter drills in schools (Temkin et al., 2020). Around the globe, policymakers, educators, and activists have addressed school safety issues. Recently, the Black Lives Matter social movement amplified the fact that 1.7 million students in the United States attend a school with a police officer but without a counselor (Blad, 2019). In sum, it is crucial to engage in theoretical and practical debate on how education systems have addressed gun violence by adopting policies and fortifying schools.

Gun violence in schools and resultant efforts to protect students and educators from gun violence are not new, nor unique to the U.S. (Levinsky, 2020). Twenty-five years before the 2018 Parkland Shooting in Florida, secondary schools from New York City to Los Angeles, particularly those predominantly serving students of color, were equipped with metal detectors, ostensibly to prevent people from carrying guns into schools (Schildkraut \& Grogan, 2019). This intensification of school safety measures also predates the 1999 Columbine Massacre in Colorado (Levinsky, 2020). In the early 1990s, few 
states had policies mandating punishment for students who brought weapons to school (Curran, 2016; Skiba \& Peterson, 1999). This changed with the passage of the Guns-Free School Zone Act (GFSZA) of 1994, which allocated federal funds to states adopting a policy that mandated expulsion of at least one year for students who brought guns to school. By the early 2000s, nearly every state and school district had a mandatory expulsion policy related to guns (Curran, 2016). This is a signal of the power of the federal government to institute widescale education policy change affecting schools across the USA.

More recently, the federal government has played a role in fortifying schools. Following the 2018 Parkland school shooting, the Trump administration created the Federal Commission on School Safety. The commission was tasked to "review safety practices and make meaningful and actionable recommendations of best practices to keep students safe" (Federal Commission on School Safety, 2018, p. 5). The commission's final report addressed three domains: prevention, protection and mitigation, and responding and recovering to school shootings. Prevention recommendations included creating positive school climate, increasing access to mental health services, improving the clarity of threat assessment policies, and rescinding Obama-era guidelines that encouraged schools to reduce exclusionary discipline rates for minority students. The protect and mitigate recommendations described how school staff should engage in safety training and that schools should improve security in the case of an active shooter, especially around entry points and classroom doors and windows. Recommendations related to responding and recovering involved encouraging schools to hold lockdown and/or active shooter drills (Levinsky, 2020). 
There has been research on trends in school safety policy, students' perceptions of safety, and effectiveness of certain programs but much of this research is atheoretical or concentrates on one school safety policy or program, rather than field-level issues associated with guns in schools and society. Further, little of this scholarship treats districts and schools as racialized organizations (Ray, 2019). As such, there is limited research on the structures and activities instituted to make schools 'safe' from guns or how these structures and activities influence the work of teachers and leaders as well as the experiences of minoritized students and families.

\section{Objectives}

This conceptual article focuses on the U.S. K-12 education system's responses to school shootings since the 1999 Columbine High School massacre. We first detail the fortification of schools over the past two decades, acknowledging highly publicized mass shooting incidents in schools. We then review existing research on the effectiveness of school safety measures, as well as the scholarship attending to the consequences of safety policies on students. Next, we apply structure-agency theory to advance arguments on the fortification of schools. In so doing, we explain the interrelation between racialized safety policies and ground-level practices in schools linked to safety. These explanations have relevance for a global audience since they are channeled by sociological concepts and urge further analyses across countries and contexts. Our discussion of fortification elucidates racialized structures shaping the implementation of safety policy, deepens understandings of structure-agency theory, and provides recommendations for scholars and practitioners concerned with gun violence in schools. 


\section{Proliferation of School Safety Policies}

Events of gun violence in schools have occurred as far back as the nineteenth century. Over the past few decades, attention to issues of school safety policy coincided with events of mass casualties in schools and the public reaction to them (Muschert, 2007). Table 1 summarizes mass shootings in U.S. schools that received nationwide media coverage over the past three decades. Agonizingly, Table 1 details only a fraction of the incidents of gun violence in schools. Indeed, at the onset of school closings due to the COVID-19 virus, March 2020 was the first month without a school shooting in the U.S. since 2002 (Lewis, 2020).

Insert Table 1 here.

\section{State Policy for Gun Safe Schools}

To address gun violence in U.S. schools, legislation and policies targeting school safety have steadily increased over the past three decades. Specifically, the Columbine, Sandy Hook, and Parkland shootings led to increases in state policies that focused on structures, facilities, and procedures for school safety (Curran et al., 2020; Schildkraut \& Grogan, 2019; Temkin et al., 2020).

At the state-level, there has been an expansion of school safety legislation. Specifically, states added 87 laws related to school building security between 1999 and 2019 (Temkin et al., 2020). The majority of these laws (57.5\%) were adopted in the two years following school shootings in Columbine (1999-2000), Sandy Hook (2013-2014), and Parkland (2018-2019). Further, by 2019, 16 states adopted laws mandating schools to conduct active shooter drills in the wake of the 2018 Parkland shooting. This acceleration of adopting policy levers to solve the problem of gun violence in schools has consequences for educators, students, and society. 


\section{Local Responses for Gun Safe Schools}

In schools, the use of metal detectors also signals the intensification of safety policy. In 1999, 9.0 percent of middle and high school students in public schools reported that their schools used metal detectors (Musu-Gillete, et al., 2018). However, by 2015, 12.3 percent reported the presence of metal detectors, in part due to increases after the Columbine and Sandy Hook school shootings (Musu-Gillete et al., 2018; Schildkraut \& Grogan, 2019). Other increases in safety measures during this period include using security cameras to monitor schools $(19.4 \%$ of schools in $1999,75.1 \%$ in 2013$)$ and stationing security guards or police officers in schools $(54.1 \%$ of schools in 1999, 69.5\% in 2015) (Musu-Gillete et al., 2018).

School Resource Officers. We underscore that the adoption of sworn law enforcement officers in schools, typically termed as School Resource Officers (SROs), varies considerably by school level, state, and the racial demographics of enrolled students. Data from the U.S. Department of Education Office of Civil Rights indicates that $67 \%$ of high schoolers attend a school with SROs, compared to $45 \%$ of middle school students and $19 \%$ of elementary school students (Lindsay et al., 2018; Musu-Gillete, et al. 2018). Some states deploy SROs more often than others. Lindsay et al. (2018) determined that over $90 \%$ of high school students in Maryland, North Carolina, South Carolina, Tennessee, and Virginia attended school with at least one SRO in comparison to less than $40 \%$ of high schoolers in Michigan, New York, and Pennsylvania.

Even more crucially than those patterns, the likelihood of attending a school with an SRO is associated with the racial demographics of the school. Specifically, 53 percent of schools in which less than 10 percent of students are Black or Hispanic have an SRO, as compared to approximately 75 percent of schools in which half of the students are Black or Hispanic (Lindsay et al., 2018). This racialized pattern of dedicating resources towards policing Black and Brown 
students inside schools represents how fortification adversely affects Black and Hispanic students in the U.S. context.

\section{Literature Review}

The literature on school safety policy tends to characterize the nature of or quantifying the impact of safety policies and procedures; however, much of this literature is atheoretical. We review results on the effectiveness of punitive deterrence measures, school resource officers, metal detectors, and other technologies targeting the problem of guns in schools.

\section{Suspension Policies}

There is little evidence that zero-tolerance policies and exclusionary disciplinary systems increase school safety. Deterrence theory_which posits that students are less likely to commit certain infractions when schools enforce penalties for committing them-is often used as a justification for exclusionary discipline practices, such as suspensions when a student is found with a weapon (Paternoster, 2010). Aligning with rational choice theory, deterrence theory assumes that people are rational actors "who both have access to the necessary information and can process such information to arrive at the optimal decision regarding their action" (Curran, 2016, p. 649). Yet research in neuroscience and developmental psychology indicates that children/adolescents are not rational actors and do not hold the same reasoning skills as adults and, as such, are more likely to exhibit risk-taking behavior (Reyna \& Farley, 2006). Thus, students may take risks, including bringing a gun to school even after learning of suspension/expulsion rules, without considering rational ramifications of their decision.

The data on suspensions suggest that suspensions are not successful in deterring behavior. Curran (2016) found that state-level zero tolerance policies were associated with increased overall suspension rates, with a notable increase for Black students. However, there 
was no association between state-level zero tolerance policies and principals' perceptions of problem behaviors, indicating that these increases in suspensions did not lead to increasing feelings of safety. Further, students who received one suspension were more likely to get suspended again in later years, implying that suspensions may not be as useful as a deterrence as school officials desire (Fabelo et al., 2011; Lacoe \& Steinberg, 2019). For these reasons, it is vital to consider how educators design and enact systems that deter gun violence in the context of schooling.

\section{School Resource Officers}

Studies analyzing whether the presence of an SRO is associated with crime, suspensions, and behavior report contradictory results. Some studies found that SRO presence decreases reported crime related to weapons, assault, and drug possession/use (e.g., Owens, 2017; Sorensen et al., 2020; Theriot, 2009; Zhang, 2019). Other studies found that serious offenses increase with the presence of SROs (e.g., Na \& Gottfredson, 2011; Zhang, 2019).

Current literature indicates the presence of SROs is associated with an increase in students being reported to law enforcement for non-serious offenses (Na \& Gottfredson, 2011; Owens, 2017; Sorenson et al., 2020; Theriot, 2009). Weisburst (2019) identified a negative association between SROs in Texas middle schools and college graduation rates. In a study drawing on administrative data from North Carolina, Sorensen, et al. (2020) found that SROs were positively associated with high school graduation rates for white students in predominantly Black and Hispanic schools yet being negatively associated with high school graduation for Black and Hispanic students in predominantly white schools. In this way

There are several potential explanations for the murky results on SROs' effects on crime, behavior, and suspensions, including variability in the nature of SROs' responsibilities and in 
their conceptualizations of discipline. The National Association of School Resource Officers (NASRO) encourages SROs to avoid directly involving themselves with student disciplinary issues that do not break the law (Canady et al., 2012; Curran et al., 2020). However, the 2009-10 School Survey on Crime and Safety from the Department of Education found that $77.6 \%$ of administrators with an SRO reported that the SRO helped maintain discipline in their school (Chaney \& Hansen, 2015). Incidents of school officers beating, harassing, or arresting students more often occur with Black and Brown students (Fabelo et al., 2011; Miller, Jean-Jacques, 2016; St. George, 2011). The ambiguity of school policies on SROs' work and, in particular, SROs' role in implementing school discipline policy can lead to student trauma caused by interactions with the police (Curran et al., 2020; James \& McCallion, 2013). Moreover, Turner \& Beneke (2020) exposed that SROs commonly contribute to the school to prison pipeline, with deleterious consequences for students of color.

\section{Metal Detectors}

Some scholars and activists have argued that metal detectors are an effective and necessary instrument for school safety (e.g., Johnson, 2000), though the success rate from other settings suggests otherwise. Tests of the ability of metal detector and x-ray machines used in US airports to identify weapons and drugs have revealed failure rates as high as $85 \%$ (Blake, 2017; Lardieri, 2017; Schildkraut \& Grogan, 2019). The current literature is not conclusive on whether these failure rates also exist in schools (Hankin, Hertz, \& Simon, 2011).

Metal detectors can have an adverse effect on students' feelings of safety (Gastic, 2010; Hankin et al., 2011; Schildkraut \& Grogan, 2019). In a study using survey data from New York City high schools, students were less likely to report that they carried guns to school if their school had a metal detector, even though all students reported similar rates of gun ownership in 
settings other than schools (Ginsberg \& Loffredo, 1993). However, the authors noted that these results may be due to students wishing to not report such conduct instead of representing a deterrent effect from metal detectors (Ginsberg \& Loffredo, 1993; Hankin et al., 2011). As Schildkraut and Grogan (2019) point out, school shootings have occurred in schools with metal detectors and security guards, pointing to limitations of these devices to prevent gun violence in schools.

\section{Security Equipment}

Under pressure to keep students and educators safe from guns, schools and parents have invested in expensive equipment including armored school building doors, bulletproof white boards, upgraded surveillance technology, and bulletproof backpacks. The costs for these items can stretch families and schools. Bulletproof backpacks cost around \$200 each (BulletBlocker, 2020), specialized security doors approximately cost $\$ 2500$ each (Remo, 2020), and the installation of bulletproof glass windows costs approximately $\$ 25,000$ (Total Security Solutions, 2014).

The vendors of these security products claim they protect against gunfire, yet academic research has not determined whether or how they improve safety for students and educators (e.g., O’Regan, 2019; Schildkraut \& Grogan, 2019). Indeed, a Washington Post survey of schools which had experienced shootings determined that "no amount of investment in security can guarantee a school protection from gun violence" (Cox \& Rich, 2018). Some commentators and scholars (e.g., Walker, 2019; Warnick \& Kapa, 2019) articulate that the hardening of schools through security equipment and protocols has adverse effects on students (i.e., over disciplining students, decreasing trust amongst students for teachers and administrators, diverting resources 
from mental health supports, and making school climate worse) that outweigh the small benefits of these products.

\section{Theoretical Framework}

This conceptual paper applies lenses from neo-institutional theory to account for the role of the environment, conceptualizations, and actors in the shifting field of school safety policy (Scott \& Davis, 2006). Specifically, these lenses permit us to examine multiple features of school safety, including its policies, logics, and leaders. In so doing, we reveal how field-level, racialized structures matter for the implementation of safety policy. We can also describe international implications regarding the fortification of schools.

Neo-institutional theory (neo-IT) treats an organizational field as containing a set of organizations, governance structures, logics, and actors (Scott, 2001). First, governance structures, with rules and regulations, play a role in shaping, controlling, and monitoring activities. With regard to school safety, governance structures range from federal and state legislation on guns (e.g., 1994 GFSZA) to district guidelines on lockdown drills and student discipline programs (Curran, 2016; Musu-Gillete, et al. 2018).

Second, logics are the deep-seated conceptualizations existing in a field (Scott et al., 2000; Thornton \& Ocasio, 1999). For example, the logics of the principalship define what principals should do to implement reforms in their schools (Rigby, 2014). We note there are multiple, competing logics of school safety. Researchers have begun considering how actors wield logics to advance change in a particular direction (Coburn, 2016; Fligstein, 2001). Third, actors, which include organizations and people, carry logics and regulations while conducting work in a field (Scott \& Davis, 2006). Thus, actors play a 
role in organizational change as policies are designed, interpreted, and implemented (Coburn, 2016; Spillane et al., 2002). Further, actors who serve as institutional entrepreneurs can make a difference in a field by pushing back against structures or further reinforcing structures (Fligstein, 2001; Hallett, 2010; Woulfin, 2016). It is crucial to draw attention to institutional entrepreneurs addressing school safety policy.

\section{Structuration}

To grapple with the relationship between field-level institutional structures and activities, we use the concept of structuration. As a branch of neo-IT, structuration focuses on the duality of structure and agency (Giddens, 1985). Structuration emphasizes the recursive, dynamic relationship between institutional structures and action (Barley \& Tolbert, 1997; Coburn, 2016; Cooney, 2007). Thus, it offers lenses to analyze the interplay between formal structures and actors' work so that researchers can simultaneously address how structure influences practices and how those practices, in turn, shape structure.

Because structuration elevates the role of policies and other structures plus people with discretion and capacity under particular conditions, it has utility for examining multiple dimensions of policy implementation (Coburn, 2016). Researchers have applied structuration to study the nature of professions and changes in the work of professionals (Barley, 1986; Kellogg, 2011). In the education field, structuration has been applied to examine the enactment of special education policies and teacher evaluation systems (Bray \& Russell, 2016; Donaldson \& Woulfin, 2018). This conceptual article discusses the structuration of fortification in the field of U.S. K-12 schooling.

Structure. Scholars treat rules, logics, and resources shaping or controlling a field as institutional structures (Giddens, 1984; Scott, 2001). Policies contain rules and ideas 
that structure institutions and organizations (Coburn, 2016). It is evident federal and state gun policies as well as district and school safety policies function as structures that influence fortification, and this influence has increased fortification over time (MusuGillete, et al. 2018; Temkin, et al., 2020).

Institutional logics are another form of structure providing guidelines for roles and activities (Goodrick \& Reay, 2011; Scott et al., 2000). It follows that logics of safety define educators' roles and channel work practices as they navigate school safety issues. Aligning with Levinsky's (2020) scholarship on lockdown policies and procedures, the logics of safety present sets of ideas on what roles, terminology, and activities are appropriate to deal with safety within the education system. These logics may ebb and flow, with different logics predominant in different contexts (Russell, 2011; Scott et al., 2000). For instance, in certain countries, states, or districts, the militarized, risk management, or transformative logic may become more (or less) taken for granted (Levinsky, 2020).

Resources are a third type of structure that permits or limits change (Scott, 2001). Specifically, resources are martialed to promote particular objectives and activities, and, if resources are limited, actors may lack capacity to fully enact activities (Coburn, 2016; Fligstein, 2001; Scott, 2001). In the U.S. education system, it is evident resources, and, more specifically, money matters for multiple outcomes (Jackson et al., 2016). Notably, although states and districts trimmed budgets for teachers, counselors, social workers, librarians, and nurses in schools (Black, 2016; Goldstein, 2019; Perry, 2016; Sparks \& Harwin, 2018; Richman, 2019), they increased funding for school safety (Cox \& Rich, 2018). During 2017, schools spent $\$ 2.8$ 
billion on school safety equipment and services; this sum does not even include the hundreds of millions of dollars spent on SROs (Cox \& Rich, 2018; Thurau \& Wald, 2019).

Racialized Structures. This array of structures for school safety-from rules and logics to resources - is not race-neutral. Rather, they are racialized (Ray, 2019). That is, the structures of school safety policy are nested within longstanding, institutionalized macro-structures and meso-systems of racism (Ray, 2019). The structures related to the fortification of schools are racialized, as are the policies, logics, and resources of school safety.

Racialized structures in the education system include the dominant conceptions of what is a "safe" school and patterns of funding in districts serving higher versus lower proportions of students of color. As previously noted, schools with higher proportions of students of color, typically situated in underserved districts, allocate more funding for SROs; they frequently apply the framing that the SRO investment will increase safety for students and educators (Turner \& Beneke, 2020). These racialized structures matter in the design and implementation of school safety policy, as Black and Brown students are more likely to interact with police officers in schools rather than counselors (Blad, 2019).

\section{Agency}

In tandem with racialized structures, people and their activities play a role in organizational stability and change (Coburn, 2016; Fligstein, 2001; Giddens, 1984). Structuration addresses agency, or the flow of action in institutions and organizations (Coburn, 2016; Giddens, 1984). In the education system, there is a flow of action for implementing safety policy as people engage in multiple activities to design, enact, and dismantle various structures. 
Researchers aiming to address issues of agency attend to the people inhabiting institutions and making a difference in organizational stability or change (Fligstein, 2001; Hallett, 2010). The literature on agency delineates how actors deploy, revise, or reject structures, including logics and regulations (Coburn, 2016). Thus, while positioned under particular conditions, people engage in various activities to alter structures. In the education literature, researchers have portrayed the agency of district leaders, principals, and teachers (Bray \& Russell, 2016; Donaldson \& Woulfin, 2018). For example, Bray \& Russell (2016) depicted special educators' discretion in enacting meeting routines aligned with special education regulations and norms. In the domain of school safety policy, multiple actors play roles in mandating, enacting, and dismantling safety structures across educational organizations.

\section{Theoretical Dimensions of Fortification}

Structuration targets the continual interplay between structure and agency (Giddens, 1984; Orlikowski, 1996). Structuration enables a clearer view of the education system's structural and agentic responses for implementing school safety policy. In this article, we highlight the recursive relationship between the structures and activities of fortification. While concentrating on the dynamics of fortification across contexts, we devote attention to the racialized structures influencing responses to school shootings in the U.S. education system.

Seeking to analyze responses to the problem of school shootings, we treat fortification as a phenomenon involving structures, ideas, and people. We define fortification as the cumulative efforts to change the school system to be "safer" from gun violence. These efforts encompass altering school facilities/buildings, modifying rules and 
conceptualizations on safety, and shifting the nature of leaders' and teachers' roles and responsibilities. We note that incidents of gun violence may trigger actors to mandate or further engage in fortification, yet this occurs under various structural conditions.

Fortification is a case of structuration because of the interplay between structures resources, and logics of school safety and the on-the-ground practices of educators, students, and community members working in the area of school safety. Those structures, in concert with the agency of actors, may accelerate or deepen schools' fortification. This article presents the racialized structure-agency dynamics of fortification in the U.S. education system. In so doing, we illuminate important dimensions of school safety policy implementation. Additionally, by treating fortification as racialized structuration, we operationalize concepts from organizational sociology and deliver a critical reminder on the role of racism across the macro, meso, and micro analytic levels (Ray, 2019). Taken together, this article provides researchers, practitioners, and reformers with a lens to comprehend and analyze the implementation of safety policy to better advocate for equitable approaches making schools safer for all students.

\section{Structure}

We hone in on three racialized structures of fortification: regulations, logics, and resources. These structures enable and constrain fortification by setting guidelines, providing conceptualizations, and supporting particular practices in the U.S. education system. Crucially, longstanding macro-forces of racism as well as anti-Blackness affect facets of these structures, such as regulations on searching students in schools serving higher versus lower proportions of students of color (Merkwae, 2015). 
Regulations. Multiple regulations operate as fortification structures. First, the Federal Gun-Free School Zones Act of 1994 provided additional federal funding to states that enacted laws mandating expulsion for students who carried weapons. The 1994 GunFree School Zones Act put forth regulations around the issue of guns on school grounds. This federal legislation structured actors' practices as well as beliefs related to safety issues. Consequently, this law contributed to nearly every state adopting zero-tolerance laws related to guns, while many also adopted zero-tolerance laws related to other weapons, drugs, and assault (Curran, 2016; Driver, 2018). Zero-tolerance regulations are racialized, with significant racial disparities in arrests for weapons as well as drugs (Fabelo, et al., 2011).

Second, state-level administrators developed guidelines requiring schools to create safety plans which include tactical procedures for responding if guns or intruders on campus. These formal plans list consequences and concrete steps for administrators, teachers, and staff to follow. For example, California developed an intricate compliance tool so district and school leaders engage in strategic planning for responding to gun violence in schools as well as communities (California Department of Education, 2020). Similarly, New York state specified each school should conduct four lockdown drills per year (New York State Homeland Security and Emergency Services, 2019). By defining rules and procedures for what to do if a student is carrying a gun or if there is an armed intruder, these structures channel activity and work to reproduce conceptions of what is a safe and secure school. Yet they tend to neglect how lockdown drills shift students' and teachers' conceptions of schools as places for learning and socialization. These guidelines 
and safety plans are racialized since administrators' biases shape their responses to these rules.

However, the structures and regulations of the education system are not entirely static. That is, change does occur in the field of school safety. Just over a week after Minneapolis police murdered George Floyd, the Minneapolis Public Schools school board voted unanimously to cancel their $\$ 1.3$ million contract with the Minneapolis Police Department (Hensley-Clancy, 2020; Retta, 2020). This occurred after years of activism from student leaders asking the school board to end their relationship with the local police (Retta, 2020). Therefore, there were shifts in the district's priorities and allocation of resources; however, violence and consistent pressure from inside and outside the district were needed to alter the structuring of school safety policy. Even so, district leaders may still lean on old habits and create internal 'safety' forces with little discernable differences from SROs (Keierleber, 2020).

Logics. Logics of school safety also play a role in structuring fortification. Logics, as the deep-seated conceptualizations providing guidelines for action, influence how educational organizations, administrators, and teachers frame and respond to guns in schools (Coburn, 2001; Scott et al., 2000). For instance, the militarization logic emphasizes rules of conduct coupled with punishments for any infractions, while the transformative logic prioritizes building a just community and repairing any damaged relationships. Further, the militarization logic supports using SROs—often armed with tasers and firearms - to address possible gun violence. In contrast, the transformative logic encourages care-, equity-, and relationship-based techniques to prevent violence in schools (Morrison \& Vaandering, 2012). 
These distinct logics push and pull fortification in different directions. Some educators may engage in work coupled to the militarization logic while others, even within the same district or school, engage in work coupled to the transformative logic (Coburn, 2016; Woulfin, 2016). For example, district and school administrators may lean towards the militarization logic, allocating resources for searching students and metal detectors, but some teachers and counselors may apply the transformative logic to serve students proactively and improve the climate and safety of the school. These clashes, or contradictions, influence the fortification of schools and the experiences of educators and students in schools.

Moreover, the patterning of logics in and across organizations is racialized. As such, educational leaders in a district serving a higher proportion of Black students may draw on different logics of safety than those in a district with a higher proportion of white students. In turn, these conceptualizations of safety steer educators' enactment of various policies (e.g., discipline policy, safety regulations, teacher hiring/development) in and through their daily work.

Resources. Resources matter for fortification because they bolster certain ideas and actors yet devalue others. In the case of school safety, resources affect the materials and technology purchased as well as staff hired to fortify schools. School safety is projected to be a near $\$ 3$ billion industry in the U.S. by 2021 (Informa, 2018)—with funds spent on metal detectors, bulletproof doors and windows, surveillance technology (e.g., video cameras), and SROs (Thurau \& Wald, 2019). This indicates the prioritization of the militarization logic and bolsters the role of safety officers over counselors and other mental health supports for students/school communities. 
Whilst metal detectors purport to detect guns and other weapons, they are both a financial and academic burden for school systems. Metal detectors cost approximately $\$ 5000$ per device, with schools also paying for trained professionals to monitor them (Schildkraut \& Grogan, 2018). Further, metal detectors significantly lengthen the school entry process, forcing schools to either stagger entry time periods or force students to come to school earlier than they would need to without metal detectors (Schildkraut \& Grogan, 2018). In sum, metal detectors, as a structure, necessitates actors modifying other structures and activities of schooling, oftentimes with limited benefits.

Resources uphold certain systems and actors while perpetuating longstanding inequities in who has access to what type of educational opportunities. Following this, resources of fortification are racialized structures (Ray, 2019). This angle is critical for understanding variability in safety structures and procedures between urban districts serving a higher proportion of students of color and many suburban school systems serving a higher proportion of white students. On the one hand - to police the school's own students — many urban districts educating predominantly Black students allocated resources to install metal detectors and patrol the entrances of school buildings (Schildkraut \& Grogan, 2019).

On the other hand, many predominantly white, higher socio-economic status, districts dedicated resources to design and build safer school facilities (e.g., bulletproof windows) to deter intruders, teacher professional development on responding to an intruder, and school counselors to support children/youth with mental health needs (Barnum, 2017). These differences in the quantity, nature, and objectives of resources for 
fortification affect leaders, teachers, staff, students, and the broader community while maintaining or exacerbating racial inequities in school quality.

\section{Agency}

Structuration attends to the ongoing relationship among agency and the structuring forces of regulations, logics, and resources. Multiple actors address the issue of guns in schools: from state and district leaders to teachers and parent/student advocacy organizations. For example, the Philadelphia Student Union has frequent meetings with district officials and is currently calling for \#PoliceFreeSchools (Petrillo, 2020). Parent groups like Moms Demand Action and Women Against Gun Violence have pressured school boards to adopt gun safety measures (Kingkade, 2020). Contrastingly, the National Association of School Resource Officers (NASRO) frequently campaign for expanding the use of SROs in schools and denying that SROs have adverse effects on students (Canady, James, \& Nease, 2012). These actors engage with different structures of fortification in different ways. That is, district leaders, principals, SROs, and members of communitybased organizations use their agency while encountering structures of school safety.

Actors' Discretion. Multiple actors play roles in advancing specific conceptions and models of school safety. These actors hold discretion and make choices as they take up and respond to the structures of school safety (Coburn, 2016). Further, they make contextualized, racialized decisions tailored to their organizational context. As a consequence, the enacted, ground-level practices of fortification may differ from the formal, written policy. For example, principals can prioritize the transformative logic over other logics, even while leading in systems with strict safety regulations and procedures (Hallett, 2010). These leaders could develop other individuals' understanding of the 
transformative model and its associated approaches to motivate shifts in a particular direction (Morrison \& Vaandering, 2012). And principals could make decisions about systems and procedures associated with reducing gun violence in schools (Weiler \& Armenta, 2014). More concretely, principals interpret safety policies, balance priorities for their school, design and refine systems, and emphasize and monitor certain activities in their building (Dunbar \& Villarruel, 2010).

As educators and other constituents use their agency to reinforce, refine, or reject structures, including the policies and logics of school safety, they can enable or constrain fortification in particular contexts. Further, there are racialized differences in the activities of fortification. That is, school leaders in an urban district may emphasize different rules or conceptualizations about safety policy as compared to school leaders in a suburban district. Through these activities, leaders reinforce different structures of fortification, perpetuating, or seeking to discontinue, racist approaches. In this manner, people and their agency make a difference in fortification - with ramifications for the implementation of school safety policy in various contexts.

\section{Duality of Structure-Agency}

Extending concepts from Giddens (1979), we explore three dimensions of the structure-agency duality: signification, legitimation, and domination. As represented in Table 2, these dimensions build upwards from communication on safety policy and norms of interaction in implementing safety policy to the usage of resources to channel safety policies and practices. Importantly, for each of the three dimensions, human interactions shape social structures that, in turn, influence other activities. It is critical to expose the nature of interactions mediating the structure-agency dynamics of fortification. 
Insert Table 2 here.

Signification. Signification is composed of the meanings held in social structure and considers how shared meanings are constructed through actors' communication (Fligstein, 2001; Giddens, 1979; Stones, 2005). In fortification, a range of stakeholders interpret and frame the issue of guns in schools, and this communication, in turn, becomes embedded into meaning structures. As educators and other actors communicate about fortification, they draw on interpretive schemes to make sense of safety policy. Simultaneously, educators' communication reproduces and/or modifies interpretive schemes which become embedded into structures of fortification.

For instance, during meetings on school safety guidelines matching state policy, educators may communicate potential solutions related to safety. On the one hand, district leaders could communicate with teachers about expectations for lockdown drills and metal detector protocols (Levinsky, 2020). This communication could draw on particular interpretive schemes, emphasizing the militarization logic. This communication would play a role in advancing the signification of fortification so that educators hold common meanings of what is a "safe" school. On the other hand, district leaders could communicate with community members about their goal for the school to be a safe place within the broader community; this discourse aligns to the transformative logic, advancing fortification in a different direction. Across scenarios, the meanings of safety and fortification are actively created and contested by actors under particular organizational conditions.

We underscore that the ongoing structuring of fortification involves educators developing a shared understanding of what is a safe school and of the strategies preventing 
gun violence. In certain contexts, educators may rely on conceptions of a school facility with metal detectors and school resource officers. In other contexts, however, communication and interpretations could develop shared understandings of a safe school as one with specialized entryways and trained school psychologists. These two meanings of a safe school are present under fortification, and it is critical to track under what racialized structures and conditions do they become taken for granted.

Legitimation. In addition to the signification of fortification, norms and rules of fortification influence how people in various roles interact and, consequently, create structures of legitimation (Giddens, 1979; Scott, 2001). The work of administrators, teachers, and advocates shapes what is deemed legitimate or appropriate in the sphere of school safety. The legitimation of fortification deems certain policies and practices as appropriate in the U.S. education system, ranging from active shooter drills to armed SROs (O’Regan, 2019). Yet educators, SROs, students, and community members do play active roles in constructing, carrying, and accepting these norms so these activities obtain and maintain legitimacy.

We underscore that fortification has altered norms on what teachers and leaders should do to implement safety policy. In particular, legitimation influenced norms of what happens in a "good," safe, school. Thus, in many U.S. schools, it is now deemed appropriate for SROs and/or police to monitor, search, and arrest students (Ryan, Katsiyannis, \& Counts, 2017). Additionally, in most U.S. schools it is now deemed appropriate for administrators and teachers to facilitate lockdown drills and to educate both educators and students on first aid techniques (e.g., using a tourniquet to stop bleeding from gunshot wounds) (Mendez, 2019). 
Across various contexts, there are distinctions in the norms and routines of fortification, ranging from interacting with police officers to practicing lockdown drills. We underscore that these norms and routines are racialized. As such, district and school leaders adopt particular norms for what should occur in schools and on the roles of teachers should play in safety. Further, educators' routines rely on people carrying and sometimes changing norms to legitimize fortification.

Regulations and resources are insufficient for changing this element of fortification. Agency matters since people are interacting, deploying norms, and furthering the legitimacy of fortification. That is, by repeatedly performing intruder drills and hiring SROs, educators normalize fortification. By applying structuration and examining issues of legitimation, we notice that neither federal gun legislation, state regulations, nor district plans in and of themselves foster fortification. Rather, the ongoing legitimation of fortification occurs as educators enact safety policy routines as part of their daily educational and pedagogical routines.

Domination. Actors wield power while allocating resources towards fortification; this produces and reproduces social structures of domination (see Table 2) (Giddens, 1979; Stones, 2005). In particular, policymakers, reformers, and educators draw on their power to push fortification toward their desired direction. While creating budgets, policymakers and administrators in certain contexts use their power to allocate funds towards metal detectors and SROs (Turner \& Beneke, 2020); this upholds the militarization logic. In other contexts, however, they use their power to allocate funds for teacher trainings on creating responsive classrooms and schools, hiring counselors, and listen and respond to 
community voices; this elevates the transformative logic. In both cases, they are exercising power to fortify schools while implementing safety policy.

More locally, district and school administrators wield their power to steer gun safety responses. These actors control funding, supports, and even time for gun safety systems and procedures (Dunbar \& Villarruel, 2010). For instance, district administrators may allocate funding for bullletproof glass in response to parents' concern about a future shooting. Or, principals may elect to practice lockdown drills in certain ways and at certain times (Levinsky, 2020). The accretion of these decision matters for the implementation of school safety policy in different contexts.

Domination structures are constituted by ground-level actors making decisions about various resources for gun safety in schools. Notably, fortification's domination structures are affected by racism and anti-Blackness, especially due to inequitable funding for schools and other social services (Horsford et al., 2018; Ray, 2019; Shedd, 2015). Whilst power and resources may be used to treat students as instigators of gun violence in some educational organizations, in other settings, power and resources may be used to protect students from external gun violence. In both cases, power and resources strengthen the racialized structures of fortification.

\section{Discussion and Conclusion}

This article contributes to the education policy literature by wrestling with the duality of racialized structures and agency in the fortification of the U.S. education system to counter the problem of gun violence in society and schools. We highlight how people, power, and racism influence the increased legitimacy and taken for grantedness of school safety policies with consequences for members of the education profession, students, and 
communities. We encourage additional analyses of the policies and activities of school safety in other countries.

This conceptual article attends to the recursive relationship between structure and agency that affects the fortification of schools. In particular, we target how three racialized structures, policy, institutional logics, and resources, channel school safety policy implementation. Crucially, we foreground how racialized structures shape actors' conceptions, policymaking, and implementation activities associated with fortification. This has relevance for researchers and practitioners in other countries who also interrogate and seek to improve structures and systems of school safety.

\section{Future Research on School Safety Policy}

This conceptual article applied existing research and media reports on school safety policy to advance an argument on fortification. We also revealed gaps in the evidence base on how educators plus students make sense of safety policies and fortification efforts. In response to these gaps, we propose several lines of research that target dimensions of fortification.

First, we encourage qualitative and quantitative research on students' and caregivers' perceptions of and experiences with the policies, structures, and activities of school safety, ranging from guidelines on lockdown drills to metal detectors and SROs' work (Levinsky, 2020). This type of research could advance our understanding of how caregivers conceptualize safety policies and strategies ranging from lockdown drills to metal detectors. Moreover, researchers should conduct comparative research to ascertain how caregivers living in different countries and contexts perceive of school safety. 
Second, it would be beneficial for scholars to apply Critical Race Theory (CRT) to study the racialized structures of school safety. The lenses of CRT would foreground issues of race and power as the education system grapples with addressing gun violence in a range of contexts (Delgado \& Stefancic, 2017; Horsford et al., 2018; Ladson-Billings \& Tate, 2006). Third, we urge scholars to clearly delineate their conception of school safety; that is, they should present their stance on how schools are safe for whom and safe from what. When scholars make explicit their vantage point, we can better comprehend the structures and practices of fortification which have multiple consequences for students, schools, and society.

Fourth, as the U.S. education system is chronically underresourced and facing budgetary challenges in the COVID era, we encourage cost-benefit analysis research on various investments in school safety (Atchison, 2020; Levin et al., 2017). The answers from this research could help state and district leaders make evidence-based decisions regarding the issue of guns in schools and society. We note that it may be time to reroute resources from fortification to the current health and wellness needs of students in the remote and in-person settings. We also point to the value of attending to how policymakers in other countries allocate funding for their education system as well as social services.

Finally, researchers should study the nature and roles of non-system actors (Rowan, 2002; Trujillo \& Woulfin, 2014) in the school safety field: Who are key actors in this field?; What ideas and resources do they martial? To what degree do they work in a responsive, equity-oriented manner? This scholarship would advance our understanding of how state and district leaders engage with various actors in the field of school safety; how they learn about new systems associated with school safety (e.g., surveillance systems, 
bulletproof glass, PD on responding to an intruder); and how their ties to various actors shape the implementation of school safety policy.

\section{Implications for Theory and Practice}

In addition to encouraging future research on school safety policy, we share recommendations for theory and practice. First, we encourage sociologists to continue grappling with how to measure and investigate issues of agency, including educators' work and routines (Coburn, 2016; Hallett, 2010). In the case of fortification, this could entail considering how district and school leaders go rogue, modifying regulations and protocols to match local needs. Second, we urge researchers to apply Ray's (2019) framework to interrogate racialized macro and meso level structures interlocking with educational policies. This could involve studying how anti-Blackness is reflected in policies within educational organizations, how anti-Blackness influences who functions as leaders in educational systems, and how leaders and teachers frame racialized logics.

Finally, in terms of practice, educational leaders should carefully construct learning opportunities and professional supports for leaders and teachers on fortification. It appears important to build the capacity of leaders and teachers on multiple components of school safety policy and practice. Specifically, educators should engage in professional development on the intersection between school safety policy and racism in addition to the routines, objectives, and consequences of such policy. We also recommend that leaders, reformers, and advocates monitor the implementation of school safety policy with an eye toward racial disparities and unintended consequences for students, communities, and educators. They should seek to answer questions such as: Who is served by enacting certain types of school safety policy; and how involved are Black and Brown youth in the 
decision-making process? In this manner, we remind practitioners and researchers positioned in different contexts and countries to work towards preventing and understanding school gun violence in an equity-oriented manner. 


\section{References}

Anderson, K. A. (2018). Policing and Middle School: An Evaluation of a Statewide School Resource Officer Policy. Middle Grades Review, 4(2), Article 7.

Atchison, D. (2020). COVID-19 and the squeeze on state education budgets. Retrieved from https://www.air.org/resource/covid-19-and-squeeze-state-education-budgets-equityimplications-new-york-state

Barley, S. R. (1986). Technology as an occasion for structuring: Evidence from observations of CT scanners and the social order of radiology departments. Administrative Science Quarterly, 31(1), 78-108.

Barley, S. R., \& Tolbert, P. S. (1997). Institutionalization and structuration: Studying the links between action and institution. Organization Studies, 18(1), 93-117.

doi:10.1177/017084069701800106

Barnum, M. (2017, March 7). "Exclusive Data: City Schools vs. Suburban Schools, See Where Security Officers Outnumber the Counselors". The 74. Retrieved from https://www.the74million.org/article/in-suburban-districts-unlike-some-neighboringcities-counselors-and-social-workers-outnumber-security/

Black, D. W. (2016). Averting educational crisis: Funding cuts, teacher shortages, and the dwindling commitment to public education. Wash. UL Rev., 94, 423.

Blad, E. (2019, March 4). "1.7 million students attend schools with police but no counselors, new data show". Education Week. Retrieved from https://blogs.edweek.org/edweek/rulesforengagement/2019/03/17_million_students_atten d_schools_with_police_but_no_counselors_new_data_show.html 
Blake, A. (2017, July 6). TSA failed to detect 95 percent of prohibited items at Minneapolis airport: Report. The Washington Times. Retrieved from https://www.washingtontimes.com/news/2017/jul/6/tsa-failed-detect-95-percentprohibited-items-minn/

Brady, K. P., Balmer, S., \& Phenix, D. (2007). School-Police Partnership Effectiveness in Urban Schools: An Analysis of New York City's Impact Schools Initiative. Education and Urban Society, 39(4), 455-478.

Bray, L. E., \& Russell, J. L. (2016). Going off script: Structure and agency in individualized education program meetings. American Journal of Education, 122(3), 367-398. doi:10.1086/685845

Bronfenbrenner, U., \& Morris, P. A. (2006). The bioecological model of human development. In W. Damon \& R. M. Lerner (Eds.), Handbook of child psychology: Theoretical models of human development (pp. 793-828). Hoboken, NJ: John Wiley.

BulletBlocker. (2020). BulletBlocker Bulletproof Backpacks. Retrieved from https://www.bulletblocker.com/bullet-proof-backpack-shield.html

California Department of Education (2020). Safe Schools Planning. Retrieved from https://www.cde.ca.gov/ls/ss/vp/safeschlplanning.asp

Canady, M., James, B., \& Nease, J. (2012). To protect \& educate: The School Resource Officer and the prevention of violence in schools. National Association of School Resource Officers (NASRO). Retrieved from https://www.nasro.org/clientuploads/AboutMission/NASRO-To-Protect-and-Educate-nosecurity.pdf

Chaney, B. W., \& Hansen, R. (2015). 2009-10 School Survey on Crime and Safety: Public-Use Data File Codebook (NCES 2015-060). U.S. Department of Education. Washington, DC: 
National Center for Education Statistics. Retrieved from

https://nces.ed.gov/pubs2015/2015060.pdf

Chapel Hill Police Department. (2018). Quarterly Report April--June 2018. Retrieved from https://www.townofchapelhill.org/home/showdocument?id=41632

Chein, J., Albert, D., O’Brien, L., Uckert, K., \& Steinberg, L. (2011). Peers increase adolescent risk taking by enhancing activity in the brain's reward circuitry. Developmental Science, 14(2), F1-F10.

Coburn, C. E. (2001). Making sense of reading: Logics of reading in the institutional environment and the classroom. (Unpublished Ph.D.). Stanford University, Stanford, CA.

Coburn, C. E. (2016). What's policy got to do with it? how the structure-agency debate can illuminate policy implementation. American Journal of Education, 122(3), 465-475. doi: $10.1086 / 685847$

Cooney, K. (2007). Fields, organizations, and agency: Toward a multilevel theory of institutionalization in action. Administration \& Society, 39(6), 687-718.

Cox, J.W, \& Rich, S. (2018, November 13). “Armored school doors, bulletproof whiteboards and secret snipers". The Washington Post. Retrieved from https://www.washingtonpost.com/graphics/2018/local/school-shootings-andcampus-safety-industry/

Curran, F. C. (2016). Estimating the effect of state zero tolerance laws on exclusionary discipline, racial discipline gaps, and student behavior. Educational Evaluation and Policy Analysis, 38(4), 647-668. 
Curran, F. C., Fisher, B. W., Viano, S. L., \& Kupchik, A. (2020). Understanding School Safety and the Use of School Resource Officers in Understudied Settings. Retrieved from https://www.ncjrs.gov/pdffiles1/nij/grants/254621.pdf

Delgado, R., \& Stefancic, J. (2017). Critical race theory: An introduction (Vol. 20). NYU Press.

Driver, J. (2018). The schoolhouse gate: Public education, the Supreme Court, and the battle for the American mind. New York, NY: Pantheon.

Dunbar, C., \& Villarruel, F. A. (2004). What a difference the community makes: Zero tolerance policy interpretation and implementation. Equity \& Excellence in Education, 37(4), 351359.

Elsass, H. J., Schildkraut, J., \& Stafford, M. C. (2016). Studying school shootings: Challenges and considerations for research. American Journal of Criminal Justice, 41(3), 444-464.

Fabelo, T., Thompson, M. D., Plotkin, M., Carmichael, D., Marchbanks III, M. P., \& Booth, E. A. (2011). Breaking schools' rules: A statewide study of how school discipline relates to students' success and juvenile justice involvement. New York: Council of State Governments Justice Center.

Federal Commission of School Safety (2018). Final report of the federal commission on school safety. Retrieved from https://www2.ed.gov/documents/school-safety/school-safetyreport.pdf

Fligstein, N. (2001). Social skill and the theory of fields. Sociological Theory, 19(2), 105-125.

Ford, D., Botelho, G., \& Conlon, K. (2015, October 27). “Spring Valley High School officer suspended after violent classroom arrest”. CNN. Retrieved from https://www.cnn.com/2015/10/27/us/south-carolina-school-arrest-video/index.html 
García, M. T., \& Castro, S. (2011). Blowout!: Sal Castro and the Chicano struggle for educational justice. Chapel Hill, NC: Univ of North Carolina Press.

Gastic, B. (2011). Metal detectors and feeling safe at school. Education and Urban Society, 43(4), 486-498.

Giddens, A. (1984). The constitution of society. Berkeley: University of California Press.

Giddens, A. (1979). Agency, structure. Central problems in social theory () UC Press.

Goodrick, E., \& Reay, T. (2011). Constellations of institutional logics: Changes in the professional work of pharmacists. Work and Occupations, 38(3), 372-416. doi:10.1177/0730888411406824

Goldstein, D. (2019, October 24). "It's more than pay: Striking teachers demand counselors and nurses". The New York Times. Retrieved from https://www.nytimes.com/2019/10/24/us/chicago-strike-support-staff.html

Hallett, T. (2010). The myth incarnate: Recoupling processes, turmoil, and inhabited institutions in an urban elementary school. American Sociological Review, 75(1), 52-74. doi:10.1177/0003122409357044

Hankin, A., Hertz, M., \& Simon, T. (2011). Impacts of metal detector use in schools: Insights from 15 years of research. Journal of School Health, 81(2), 100-106.

Hensley-Clancy, M. (2020, June 2). "Minneapolis Public Schools voted to end its contract with the city's police after the death of George Floyd". BussFeed News. Retrieved from https://www.buzzfeednews.com/article/mollyhensleyclancy/minneapolis-schools-policegeorge-floyd-protests

Horsford, S. D., Scott, J. T., \& Anderson, G. L. (2018). The politics of education policy in an era of inequality: Possibilities for democratic schooling. Routledge. 
Jackson, C. K., Johnson, R. C., \& Persico, C. (2016). The effects of school spending on educational and economic outcomes: Evidence from school finance reforms. The Quarterly Journal of Economics, 131(1), 157-218.

James, N., \& McCallion, G. (2013). School Resource Officers: Law Enforcement Officers in Schools. Washington, DC: Congressional Research Service. Retrieved from: https://fas.org/sgp/crs/misc/R43126.pdf

Johnson, R. S. (2000). Metal detector searches: An effective means to help keep weapons out of schools. JL \& Educ., 29, 197.

Kafka, J. (2011). The history of "zero tolerance" in American public schooling. New York, NY: Palgrave Macmillan.

Keierleber, M. (2020, August 13). "Exclusive: After Ending Police Contract, Minneapolis Schools Consider Former Cops for Revamped School Safety Role — and Activists Fear a 'Dangerous' National Trend”. The 74. Retrieved from https://www.the74million.org/article/exclusive-after-ending-police-contract-minneapolisschools-consider-former-cops-for-revamped-school-safety-role-and-activists-fear-adangerous-national-trend/

Kellogg, K. C. (2011). Challenging operations: Medical reform and resistance in surgery. Chicago, IL: University of Chicago Press.

Kingkade, T. (2020, February 10). "How moms are quietly passing gun safety policy through school boards". NBC News. Retrieved from https://www.nbcnews.com/news/usnews/how-moms-are-quietly-passing-gun-safety-policy-through-school-n1132891

Lacoe, J., \& Steinberg, M. P. (2019). Do suspensions affect student outcomes?. Educational Evaluation and Policy Analysis, 41(1), 34-62. 
Ladson-Billings, G., \& Tate, W. F. (2006). Toward a critical race theory of education. Critical race theory in education: All God's children got a song, 11, 30 .

Lardieri, A. (2017, November 9). TSA fails most tests in undercover operation. US News and World Report. Retrieved from https://www.usnews.com/news/nationalnews/articles/2017-11-09/tsa-fails-most-tests-in-undercover-operation

Levin, H. M., McEwan, P. J., Belfield, C., Bowden, A. B., \& Shand, R. (2017). Economic evaluation in education: Cost-effectiveness and benefit-cost analysis. SAGE publications.

Levinsky, Z. (2020). “Confronting [the shooter] could save your life... or end it": school lockdowns and the blending of pastoral care with risk management. Journal of Education Policy, 1-19.

Levy, G. (2013, March 7). "8-year-old handcuffed for tantrum”. UPI. Retrieved from https://www.upi.com/blog/2013/03/07/8-year-old-handcuffed-for$\underline{\text { tantrum/2621362666107/ }}$

Lewis, S. (2020). March 2020 was the first March without a school shooting in the U.S. since 2002. Retrieved from https://www.cbsnews.com/news/coronavirus-first-march-withoutschool-shooting-since-2002-united-states/

Lindsay, C.A., Lee, V., \& Lloyd, T. (2018). The prevalence of police officers in US schools. Urban Institute. Retrieved from https://www.urban.org/urban-wire/prevalence-police$\underline{\text { officers-us-schools }}$

Mendez, M. (2019). Texas could consider requiring gunshot first aid training in public schools. Retrieved from https://www.dallasnews.com/news/politics/2019/09/12/texas-couldconsider-requiring-gunshot-first-aid-training-in-public-schools/ 
Merkwae, A. (2015). Schooling the police: Race, disability, and the conduct of school resource officers. Mich. J. Race \& L., 21, 147.

Miller, M. \& Jean-Jacques, W. (2016). Is School Policing Racially Discriminatory? Washington, DC: The Century Foundation. Retrieved from: https://tcf.org/content/commentary/schoolpolicing-racially-discriminatory/?session=1\&session=1

Morrison, B. E., \& Vaandering, D. (2012). Restorative justice: Pedagogy, praxis, and discipline. Journal of school violence, 11(2), 138-155.

Muschert, G. W. (2007). Research in school shootings. Sociology compass, 1(1), 60-80.

Musu-Gillette, L., Zhang, A., Wang, K., Zhang, J., Kemp, J., Diliberti, M., \& Oudekerk, B. A. (2018). Indicators of school crime safety: 2017. Washington, DC: U.S. Department of Education \& U.S. Department of Justice.

Na, C. \& Gottfredson, D. C. (2011). Police Officers in Schools: Effects on School Crime and the Processing of Offending Behaviors. Justice Quarterly, 30(4), 1-32.

New York State Department of Homeland Security and Emergency Services. (2019). New York StateSchool Violence/Active Shooter Resource Guide. Retrieved from http://www.dhses.ny.gov/planning/nys-resourceguides/documents/School Violence Active Shooter Resource Guide.pdf

Orlikowski, W. J. (1996). Improvising organizational transformation over time: A situated change perspective. Information Systems Research, 7(1), 63-92.

Owens, E. (2017). Testing the school-to-prison pipeline. Journal of Policy Analysis and Management, 36(1), 11-37.

Paternoster, R. (2010). How much do we really know about criminal deterrence?. The Journal Of Criminal Law and Criminology, 765-824. 
Perry, G. (2016, April 18). "In the know: Budget cuts mean end of school social worker program”. Oklahoma Policy Institute. Retrieved from https://okpolicy.org/know-budgetcuts-mean-end-school-social-worker-program/

Petrillo, M. (2020, June 25). “Philadelphia Student Union Calling For Police-Free Schools In City Amid National Protests Demanding Police Reform”. CBS Philly. Retrieved from https://philadelphia.cbslocal.com/2020/06/25/philadelphia-student-unioncalling-for-police-free-schools-in-city-amid-national-protests-demanding-policereform/

Ray, V. (2019). A theory of racialized organizations. Am Sociol Rev, 84(1), 26-53. doi:10.1177/0003122418822335

Reinstein, J. (2019, December 16). “A Police Officer Who Slammed An 11-Year-Old To The Ground Has Reportedly Been Fired”. Buzzfeed News. Retrieved from https://www.buzzfeednews.com/article/juliareinstein/school-resource-officer-slammed$\underline{\text { middle-school-north-vance }}$

Remo Security Doors. (2020). Turning classrooms into safe rooms. Retrieved from https://remosecuritydoors.com/school-doors/

Retta, M. (2020, June 19). "Minneapolis Public Schools Abolished Their Police First". The Nation. Retrieved from https://www.thenation.com/article/activism/minneapolispublic-schools/

Reyna, V. F., \& Farley, F. (2006). Risk and rationality in adolescent decision making: Implications for theory, practice, and public policy. Psychological Science in the Public Interest, 7, 1-44. 
Richman, T. (2019, March 1). "Baltimore sees decline in school counselor positions". The Baltimore Sun. Retrieved from https://www.baltimoresun.com/education/bs-md-ci-suninvestigates-school-counselors-20180301-story.html

Russell, J. L. (2011). From Child's garden to academic press: The role of shifting institutional logics in redefining kindergarten education. American Educational Research Journal, 48(2), 236-267. doi:10.3102/0002831210372135

Ryan, J. B., Katsiyannis, A., Counts, J. M., \& Shelnut, J. C. (2018). The growing concerns regarding school resource officers. Intervention in School and Clinic, 53(3), 188192.

Schildkraut, J., Elsass, H. J., \& Meredith, K. (2018). Mass shootings and the media: Why all events are not created equal. Journal of Crime and Justice, 41(3), 223-243.

Schildkraut, J., \& Grogan, K. (2019). Are Metal Detectors Effective at Making Schools Safer?. WestEd. Retrieved from https://www.wested.org/wpcontent/uploads/2019/04/resource-are-metal-detectors-effective-at-making-schoolssafer.pdf

Scott, W. R., Ruef, M., Mendel, P., Caronna,C. (2000). Institutional change and healthcare organizations. Chicago: University of Chicago Press.

Scott, W. R., \& Davis, G. F. (2006). Organizations and organizing: Rational, natural, and open system perspectives. Upper Saddle River, NJ: Pearson Prentice Hall.

Scott, W. R. (2001). Institutions and organizations. Thousand Oaks, CA: Sage Publications.

Skiba, R., \& Peterson, R. (1999). The dark side of zero tolerance: Can punishment lead to safe schools?. The Phi Delta Kappan, 80(5), 372-382. 
Sorensen, L., Shen, Y., \& Bushway, S.D. (2020). Making Schools Safer and/or Escalating Disciplinary Response: A Study of Police Officers in North Carolina Schools. Retrieved from https://ssrn.com/abstract=3577645

Sparks, S.D., \& Harwin, A. (2018, May 16). "Schools see steep drop in librarians, new analysis finds". Education Week. Retrieved from https://www.edweek.org/ew/articles/2018/05/16/schools-see-steep-drop-in-librariansnew.html

St. George, D. (2011, August 21). In Texas schools, response to misbehavior is questioned. The Washington Post. Retrieved from https://www.washingtonpost.com/local/education/in-texas-schools-a-criminalresponse-to-misbehavior/2011/08/04/gIQA5EG9UJ story.html

Stones, R. (2005). Structuration theory. Macmillan International Higher Education.

Temkin, D., Stuart-Cassel, V., Lao, K., Nuñez, B., Kelley, S., \& Kelley, C. (2020). The evolution of state school safety laws since the Columbine school shooting. Child Trends. Retrieved from https://www.childtrends.org/publications/evolution-state-school-safetylaws-columbine

Theriot, M. T. (2009). School resource officers and the criminalization of student behavior. Journal of Criminal Justice, 37(3), 280-287.

Thornton, P. \& Ocasio, W. (1999). Institutional logics and the historical contingency of power in organizations: Executive succession in the higher education publishing industry, 19581999. American Journal of Sociology, 105(3), 801-843. 
Thurau, L. \& Wald, J. (2019, March 12). "We are spending millions to put more cops in schools. What could go wrong?" Education Week. Retrieved from https://www.edweek.org/ew/articles/2019/03/13/we-are-spending-millions-to-put$\underline{\text { more.html }}$

Toohey, G., \& Weiner, J. (2019, November 9). “Orange deputy fired after video showed him yanking middle school girl by her hair". Orlando Sentinel. Retrieved from https://www.orlandosentinel.com/news/crime/os-ne-orange-school-resource-officerremoved-after-inappropriate-force-20191108-efwod23yu5az5i4x12lt6dbk4y-story.html

Total Security Systems. (2014). Cost and pricing of a bulletproof glass system for schools. Total Security Solutions. Retrieved from https://www.tssbulletproof.com/blog/costpricing-bulletproof-glass-system-schools/

Turner, E. O., \& Beneke, A. J. (2020). 'Softening'school resource officers: the extension of police presence in schools in an era of Black Lives Matter, school shootings, and rising inequality. Race Ethnicity and Education, 23(2), 221-240.

UNC School of Education. (2018, December 20). Session I.2 - Beyond the shieldIntegrating SROs into school supports for student safety and wellbeing [Video]. Vimeo. https://vimeo.com/307520560

Walker, T. (2019, February 14). “'School hardening' not making students safer, say experts". NEAToday. Retrieved from http://neatoday.org/2019/02/14/schoolhardening-not-making-students-safer/

Weiler, S. C., \& Armenta, A. D. (2014). The fourth R-Revolvers: Principal perceptions related to armed school personnel and related legal issues. The Clearing House: A 
Journal of Educational Strategies, Issues and Ideas, 87(3), 115-118. doi:10.1080/00098655.2014.891891

Warnick, B.R., \& Kapa, R. (2019, Spring). "Protecting students from gun violence". EducationNext. Retrieved from https://www.educationnext.org/protecting-studentsfrom-gun-violence-does-target-hardening-do-more-harm-than-good/

Weisburst, E. K. (2019). Patrolling Public Schools: The Impact of Funding for School Police on Student Discipline and Long-Term Education Outcomes. Journal of Policy Analysis and Management, 38(2), 338-365.

Zhang, G. (2019). The Effects of a School Policing Program on Crime, Discipline, and Disorder: A Quasi-Experimental Evaluation. American Journal of Criminal Justice, 44, 45-62. 
Table 1

Mass Shootings in U.S. Schools

\begin{tabular}{|l|l|}
\hline \multicolumn{1}{|c|}{ Date } & \multicolumn{1}{c|}{ Description } \\
\hline January 1989 & $\begin{array}{l}\text { In Stockton, California, a 24-year-old man killed 5 children and wounded } \\
32 \text { others (SE Asian refugees) before killing himself at an elementary } \\
\text { school. }\end{array}$ \\
\hline March 1998 & $\begin{array}{l}\text { Two children (11 and 13) in Arkansas killed a teacher and four students at } \\
\text { their middle school. }\end{array}$ \\
\hline April 1999 & $\begin{array}{l}\text { Two Columbine High School students in Colorado killed 12 students, } 1 \\
\text { teacher, and themselves and also injured 21 others. }\end{array}$ \\
\hline December 2012 & $\begin{array}{l}\text { In Newtown, Connecticut, a 20-year-old killed 20 children and six adults at } \\
\text { an elementary school before killing himself. }\end{array}$ \\
\hline
\end{tabular}


Table 2

Three Pillars of the Structure-Agency Duality

\begin{tabular}{|l|l|l|l|}
\hline Structure & Structures of Signification & Structures of Legitimation & Structures of \\
& & & Domination \\
\hline Modality & Interpretive schemes & Norms & Resources \\
\hline Agency & Communicating & Permitting interactions & Wielding power \\
\hline
\end{tabular}

